\title{
PERAN DAN FUNGSI DAI DALAM PERSPEKTIF PSIKOLOGI DAKWAH
}

\author{
Agus Salim \\ Institut Agama Islam Negeri Langsa \\ Email: aagussalim34@gmail.com
}

\begin{abstract}
Abstrak
Tulisan ini membahas tentang peran dan fungsi dai dalam perspektif psikologi dakwah. Dakwah merupakan kewajiban setiap muslim. Sebagai dai tentu saja kita ingin mencapai kesukesesan dalam mencapai tugas dakwah. Salah satu bentuk keberhasilan dalam dakwah adalah berubahnya sikap kejiwaan seseorang. Psikologi dakwah mempedomani kegiatan dakwah, maka tujuan psikologi dakwah dalam peran dan fungsi dai memberikan pandangan tentang mungkinnya dilakukan perubahan tingkah laku atau sikap mental psikologis sasaran dakwah sesuai dengan pola kehidupan yang dikehendaki oleh ajaran agama yang didakwabkean oleh aparat dakwah/dai. Peran dan fungsi dai sebagai juru dakwah adalah salah satu faktor dalam kegiatan dakwah yang menempati posisi sangat penting dalam berhasil atau tidaknya kegiatan dakwah. Dai professional yang mengkhususkan diri di bidang dakwah, seyogianya memiliki kepribadian yang baik untuk. menunjang keberhasilan dakwah baik yang bersifat rohani atau yang bersifat fisik. Hasil yang ingin diperoleh dengan pengetabuan tentang tulisan ini, diharapkan kita dapat melaksanakan tugas dakwah dengan pendekatan kejiwaan sehingga hal yang diharapkan peran dan fungsi seorang dai benar-benar dapat dipahami oleb seorang dai sebagai mubalig dan kondisi objek dakwah sebagai mad'ú.
\end{abstract}

Kata Kunci: Peran, Fungsi, Dai, Psikologi Dakwah

\section{A. Pendahuluan}

Manusia diciptakan oleh Allah dengan membawa tugas dan amanah yang sangat berat. Salah satu tugas manusia di bumi ini adalah sebagai khalifah fi alardl. Setiap manusia memiliki tugas sebagai pemimpin. Di mana seorang pemimpin itu harus mampu menciptakan ketentraman, kedamaian, keadilan dan kesejahteraan. Membenarkan atau mengarahkan segala sesuatu yang dirasa belum baik dan tidak sesuai dengan apa yang diperintahkan oleh Allah selaku Sang Khalik. Manusia memiliki tugas untuk menyeru kepada manusia yang lain yang belum sesuai dengan yang diperintahkan Allah Swt., dan manusia memiliki kewajiban beramar makruf nahi munkar.

Dakwah merupakan kewajiban setiap muslim. Sebagai dai tentu saja kita ingin mencapai kesuksesan dalam mencapai tugas dakwah. Salah satu bentuk keberhasilan dalam dakwah adalah berubahnya sikap kejiwaan seseorang. Dari tidak cinta Islam menjadi cinta, dari tidak mau beramal saleh menjadi giat melakukannya, dari cinta kemaksiatan menjadi benci dan tertanam dalam jiwanya rasa senang terhadap kebenaran ajaran Islam, begitulah seterusnya.

Karena dakwah bermaksud mengubah sikap kejiwaan seorang mad' $\bar{u}$, maka pengetahuan tentang psikologi dakwah menjadi sesuatu yang sangat 
penting. Dengan pengetahuan tentang psikologi dakwah ini, diharapkan kita dapat melaksanakan tugas dakwah dengan pendekatan kejiwaan sehingga hal yang diharapkan peran dan fungsi seorang dai benar-benar dapat dipahami oleh seorang dai sebagai mubalig dan kondisi objek dakwah sebagai mad' $\bar{u}$. Sebagaimana Rasul Saw. dalam dakwahnya memang sangat memperhatikan tingkat kesiapan jiwa orang yang didakwahinya dalam menerima pesan-pesan dakwah.

Saat ini banyak sekali fenomena-fenomena negatif yang terjadi di sekitar kita, dalam artian, banyak sekali umat manusia yang jauh dari apa yang Allah perintahkan kepada manusia itu sendiri. Tugas lain dari manusia adalah beribadah kepada Allah, bukan hanya manusia saja, melainkan jin juga malaikat. Tapi masih banyak sekali manusia yang belum menjalankan tugasnya, maka di sinilah juga tugas kita manusia dan para dai untuk meluruskan hal-hal yang seperti itu dan mengajak mereka yang belum menjalankan perintah Allah untuk melaksanakannya. Sebagian besar mereka mungkin memang mengaku sebagai seorang muslim, tapi apakah mereka sudah benar-benar melakukan tugasnya sebagai seorang muslim.

\section{B. Pengertian Psikologi Dakwah}

\section{Pengertian Psikologi}

Dalam lapangan ilmu pengetahuan, psikologi merupakan salah satu pengetahuan yang tergolong dalam "empirical science" yaitu ilmu pengetahuan yang didasarkan pada pengalaman manusia. Walaupun pada perkembangannya bersumber pada filsafat yang bersifat spekulatif.

Psikologi menurut bahasa berasal dari kata Yunani yang terdiri dari dua kata: Psyche dan logos. Psyche berarti jiwa dan logos berarti ilmu, jadi psikologi secara bahasa dapat berarti "Ilmu Jiwa". Namun pengertian ilmu jiwa itu sendiri masih kabur dan belum jelas. Hal ini disebabkan karena para sarjana belum mempunyai kesepakatan tentang jiwa itu sendiri. Menurut Sarlito (2000: 3), tidak ada seorang pun seseorang yang tahu dengan seseungguhnya apa yang dimaksud dengan jiwa itu sendiri, karena jiwa adalah suatu kekuatan yang abstrak yang tidak tampak oleh pancaindra wujud dan zatnya, melainkan yang tampak hanya gejalagejalanya saja.

Beberapa sarjana modern mencoba mengemukakan beberapa definisi psikologi di antaranya Wilhem Wundt, (dalam Arifin, 1976: 19) mendefinisikan sebagai ilmu pengetahuan yang mempelajari atau menyelidiki pengalaman yang timbul dalam diri manusia, seperti pengalaman pancaindra, merasakan sesuatu, berpikir, berkehendak, dan bukan mempelajari pengalaman yang diluar diri manusia, karena pengalaman yang demikian menjadi objek kajian ilmu pengetahuan alam. Jhon C. Ruch (1984: 4) mendefinisikan psikologi sebagai ilmu tentang aktivitas perilaku dan mental. Ernest Hilgert (1962: 2) mengatakan, "Psychology is the science that studies the behavior of men and other animals" (Ilmu jiwa dapat diberikan batasan sebagai ilmu pengetahuan yang mempelajari tingkah laku dari manusia dan manusia lainnya). 
Di sisi lain secara sederhana psikologi juga sering disebut sebagai ilmu yang mempelajari tingkah laku manusia yang merupakan gejala dari jiwanya. Sedangkan pengertian atau definisi yang lebih terperinci menyebutkan bahwa psikologi adalah ilmu pengetahuan yang mempelajari tingkah laku lahiriah manusia dengan menggunakan metode observasi secara obyektif, seperti terhadap rangsang (stimulus) dan jawaban (respon) yang menimbulkan tingkah laku.

Definisi tersebut di atas mengesankan bahwa kegunaan psikologi terbatas hanya untuk menguraikan atau mengungkap apa yang ada di balik tingkah laku manusia. Dalam keadaan tertentu, kebutuhan seseorang memang dapat saja terbatas hanya ingin mengetahui faktor kejiwaan apa yang menyebabkan tingkah laku tertentu orang lain, tapi di saat yang lain, misalnya bagi seorang yang sedang merencanakan suatu kegiatan yang melibatkan banyak orang di mana banyak kemungkinan bisa terjadi, maka psikologi dapat membantunya meramalkann kira-kira tingkah laku apa yang bakal dilakukan oleh sebagian atau keseluruhan dari orang-orang yang diamatinya.

\section{Pengertian Dakwah}

Dalam bahasa Arab, da'wah atau da'watun biasa digunakan untuk arti-arti: Undangan, ajakan dan seruan yang kesemua menunjukkan adanya komunikasi antara dua pihak dan upaya mempengaruhi pihak lain. ukuran keberhasilan undangan, ajakan atau seruan adalah manakala pihak kedua yakni yang diundang atau diajak memberikan respon positif yaitu mau datang dan memenuhi undangan itu. Jadi kalimat dakwah mengandung muatan makna aktif dan menantang, berbeda dengan kalimat tablig yang artinya menyampaikan. Ukuran keberhasilan seorang dai sebagai mubaligh adalah manakala ia berhasil menyampaikan pesan Islam dan pesannya sampai (wamà 'alainā illā al-balägh), sedangkan bagaimana respon masyarakat tidak menjadi tanggung jawabnya. Dari sini kita juga dapat menyebutkan apa sebenarnya tujuan dari dakwah itu sendiri? Adapun tujuan dari dakwah adalah untuk menumbuhkan pengertian, kesadaran, penghayatan dan pengalaman ajaran agama yang dibawakan oleh aparat dakwah/dai.

Dengan demikian maka dapat dirumuskan bahwa dakwah ialah usaha mempengaruhi orang lain agar mereka bersikap dan bertingkah laku seperti apa yang didakwahkan oleh dai. Setiap dai agama pun pasti berusaha mempengaruhi orang lain agar mereka bersikap dan bertingkah laku sesuai dengan agama mereka. Dengan demikian pengertian dakwah islam adalah upaya mempengaruhi orang lain agar mereka bersikap dan bertingkah laku islami (memeluk agama Islam).

Sebagai perbuatan atau aktifitas, dakwah adalah peristiwa komunikasi di mana dai menyampaikan pesan melalui lambang-lambang kepada mad $\bar{u}$, dan mad'u menerima pesan itu, mengolahnya dan kemudian meresponnya. Jadi, proses saling mempengaruhi antara dai dan mad' $\bar{u}$ adalah merupakan peristiwa mental. Dengan mengacu pada pengertian psikologi, maka dapat dirumuskan bahwa psikologi dakwah ialah ilmu yang berusaha menguraikan, meramalkan 
dan mengendalikan tingkah laku manusia yang terkait dalam proses dakwah. Psikologi dakwah berusaha menyingkap apa yang tersembunyi di balik perilaku manusia yang terlibat dalam dakwah, dan selanjutnya menggunakan pengetahuan itu untuk mengoptimalkan pencapaian tujuan dari dakwah itu.

\section{Pengertian Psikologi Dakwah}

Secara harfiah, psikologi artinya "ilmu jiwa" berasal dari kata yunani psyce "jiwa” dan logos "ilmu”. Akan tetapi yang dimaksud bukanlah ilmu tentang jiwa. Psikologi adalah ilmu yang mempelajari tingkah laku manusia sebagai gambaran dari keadaan jiwanya. Adapun dakwah merupakan usaha mengajak manusia agar beriman kepada Allah Swt. dan tunduk kepada-Nya dalam kehidupan di dunia ini, dimanapun ia berada dan bagaimana pun situasi serta kondisinya.

Dengan demikian, psikologi dakwah adalah ilmu yang mempelajari tingkah laku manusia yang merupakan gambaran dari kejiwaannya guna diarahkan kepada iman takwa kepada Allah Swt. Bila disederhanakan bisa juga dengan pengertian, dakwah dengan pendekatan kejiwaan.

Pengertian dari Psikologi Dakwah yaitu psikologi dan ilmu dakwah. Pengetahuan tentang Ilmu Jiwa atau Psikologi diperlukan karena Psikologi Dakwah memang merupakan bagian dari Psikologi, yakni Psikologi Terapan. Ilmu Dakwah juga sangat relevan karena Psikologi Dakwah ini adalah ilmu bantu bagi kegiatan dakwah. Boleh jadi pengguna ilmu ini adalah dai yang psikolog yang suka berdakwah.

Berdasarkan definisi-definisi dakwah yang telah disebutkan di atas, dapat disimpulkan bahwa psikologi dakwah didefenisikan sebagai ilmu pengetahuan yang mempelajari tentang gejala-gejala hidup kejiwaan manusia yang terlibat dalam proses kegiatan dakwah.

Psikologi dakwah dapat juga diberi batasan sebagai ilmu yang mempelajari tentang tingkah laku manusia yang merupakan cerminan hidup kejiwaannya untuk diajak kepada pengalaman ajaran-ajaran Islam demi kesejahteraan hidup manusia dunia dan akhirat (Mubarok, 2006: 8)

\section{Dai dalam Perspektif Psikologi Dakwah}

\section{Pengertian Dai}

Kata dai berasal dari bahasa Arab bentuk mudrakar (laki-laki) yang berarti orang yang mengajak, kalau mu'annas (perempuan) disebut daiyah (AS dan Aliyudin, 2009: 73). Sedangkan dalam Kamus Besar Bahasa Indonesia, dai adalah orang yang pekerjaannya berdakwah, pendakwah: melalui kegiatan dakwah para dai menyebarluaskan ajaran Islam. Dengan kata lain, dai adalah orang yang mengajak kepada orang lain baik secara langsung atau tidak langsung, melalui lisan, tulisan, atau perbuatan untuk mengamalkan ajaran-ajaran Islam atau menyebarluaskan ajaran Islam, melakukan upaya perubahan kearah kondisi yang lebih baik menurut Islam.

Dai dapat diibaratkan sebagai seorang guide atau pemandu terhadap orang-orang yang ingin mendapat keselamatan hidup dunia dan akhirat. Dalam hal ini dai adalah seorang petunjuk jalan yang harus mengerti dan memahami 
terlebih dahulu mana jalan yang boleh dilalui dan yang tidak boleh dilalui oleh seorang muslim, sebelum ia memberi petunjuk jalan kepada orang lain. Ini yang menyebabkan kedudukan seorang dai di tengah masyarakat menempati posisi penting, ia adalah seorang pemuka (pelopor) yang selalu diteladani oleh masyarakat di sekitarnya.

Segala perbuatan dan tingkah laku dari seorang dai akan dijadikan tolak ukur oleh masyarakatnya. Dai akan berperan sebagai seorang pemimpin di tengah masyarakat walau tidak pernah dinobatkan secara resmi sebagai pemimpin. Kemunculan dai sebagai pemimpin adalah kemunculan atas pengakuan masyarakat yang tumbuh secara bertahap. Oleh karena itu, seorang dai harus selalu sadar bahwa segala tingkah lakunya selalu dijadikkan tolak ukur oleh masyarakatnya sehingga ia harus memiliki kepribadian yang baik.

\section{Peran Dai dan Kepribadiannya}

Peran dai sebagai juru dakwah (dai) adalah salah satu faktor dalam kegiatan dakwah yang menempati posisi sangat penting dalam berhasil atau tidaknya kegiatan dakwah. Dai professional yang mengkhususkan diri di bidang dakwah. Seyogianya memiliki kepribadian yang baik untuk menunjang keberhasilan dakwah baik yang bersifat rohani atau yang bersifat fisik.

Sosok dai yang memiliki kepribadian tinggi dan tak pernah kering adalah pribadi Rasulullah Saw. serta kesaksian sahabat yang selalu mendampinginya. Diisyaratkan dalam surat al-Ahzāb ayat 21 yang berbunyi:
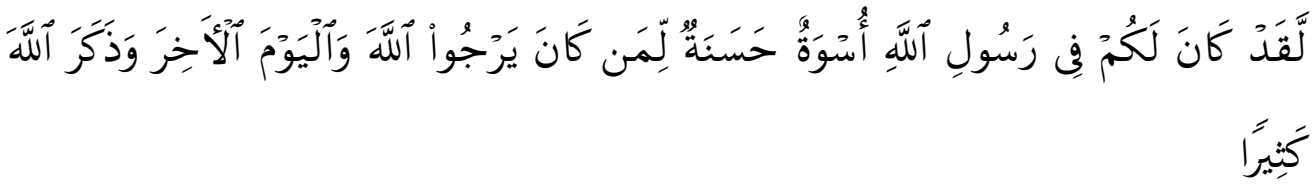

"Sesunggubnya telah ada pada diri Rasulullah itu suri teladan yang baike bagi kamu (yaitu) bagi orang yang mengharapkan (Rahmat) Allah dan (kedatangan) hari Akbir dan dia banyak menyebut Allah".

Menurut Enjang AS dan Aliyudin (2009) dai dalam prespektif ilmu komunikasi dapat dikategorikan sebagai komunikator yang bertugas menyebarkan dan menyampaikan informasi-informasi dari sumber (source) melalui saluran yang sesuai (chanel) pada komunikan (receiver). Untuk menjadi komunikator yang baik dituntut adanya kredibilitas yang tinggi yaitu suatu tingkat kepercayaan yang tinggi padanya dari komunikannya. Komunikator yang baik adalah komunikator yanag mampu menyampaikan informasi atau pesan (message) kepada komunikan sesuai dengan yang diinginkan.

Adapun kredibilitas yang dimilki dai tidaklah tumbuh dengan sendirinya, melainkan harus dibina dan terus dikembangkan. Seorang dai yang berkredibilitas tinggi adalah seorang yang mempunyai kompetensi di bidang yang ingin ia sebarkan, mempunyai jiwa yang tulus dalam beraktifitas, senang terhadap pesan-pesan yang ia miliki, berbudi luhur serta mempunyai status yang cukup walau tidak harus tinggi. Dari sana berarti seorang dai yang ingin memiliki kredibilitas tinggi harus berupaya membentuk dirinya dengan sungguh-sungguh (Muhaemin, 1994:68). Dari penjelasan di atas, menunjukkan bahwa di antara 
aspek yang mampu membangun kredibilitas adalah aspek yang berkaitan dengan kepribadian, sebuah sifat hakiki pada seorang dai (AS dan Aliyudin, 2009: 76).

Kepribadian yang harus dimiliki oleh seorang dai terbagi menjadi dua yaitu kepribadian yang bersifat rohaniah dan jasmaniah. Adapun penjabarannya adalah sebagai berikut:

\subsection{Kepribadian yang Bersifat Rohani}

Kriteria kepribadian yang baik sangat menentukan keberhasilan dakwah, karena pada hakikatnya berdakwah tidak hanya menyampaikan teori, tapi juga harus memberikan teladan bagi umat yang diseru. Keteladanan jauh lebih besar pengaruhnya daripada kata-kata, hal ini sejalan dengan ungkapan hikmah "kenyataan itu lebih menjelaskan dari ucapan". Klasifikasi kepribadian dai yang bersifat rohaniah mencangkup sifat, sikap, dan kemampuan diri pribadi dai. Ketiga masalah tersebut mencangkup keseluruhan kepribadian yang harus dimiliki (Faizah dan Effendi, 2009: 90).

\section{a. Sifat-Sifat Dai}

1). Beriman dan Bertakwa kepada Allah

Takwa dengan sebenar-benarnya takwa, mengimani dan mengikuti aturan-aturan-Nya, melaksanakan segala perinta-Nya dan menjauhi segala yang dilarang-Nya. Sifat dasar dai ini dijelaskan Allah Swt. dalam Alquran:



"Apakah kamu menyurub manusia berbuat kebaikan padahal kamu lupa terhadap dirimu sendiri sedangkan kamu sendiri membaca kitab Tuhan. Apakah kamu tidak berpikir." (QS. Al-Baqarah/2 : 44)

\section{2). Ahli Taubat}

Sifat taubat dalam diri dai, berarti ia harus mampu untuk lebih menjaga atau takut untuk berbuat maksiat atau dosa dibandingkan orang-orang yang menjadi mad'í-nya. Jika ia merasa telah melakukan dosa atau maksiat hendaklah ia bergegas untuk bertaubat dan menyesali atas perbuatannya dengan mengikuti panggilan Ilahi.

\section{3). Ahli Ibadah}

Seorang dai adalah mereka yang selalu beribadah kepada Allah dalam setiap gerakan, perbuatan atau perkataan di mana pun dan kapan pun. Dan segala ibadahnya ditujukan dan diperuntukkan hanya kepada Allah, dan bukan karena manusia (riya').

\section{4). Amanah dan Shiddiq}

Amanah (terpercaya) dan Shidq (jujur) adalah sifat utama yang harus dimiliki seorang dai sebelum sifat-sifat yang lain, karena ia merupakan sifat yang dimiliki oleh seluruh para nabi dan rasul. Amanah dan shidq adalah dua sifat yang selalu ada bersama, karena amanah selalu bersamaan dengan shidq 
(kejujuran), maka tidak ada manusia jujur yang tidak terpercaya, dan tidak ada manusia terpercaya yang tidak jujur. Amanah dan shidq merupakan hiasan para nabi dan orang-orang saleh, dan mestinya juga menjadi hiasan dalam pribadi dai karena apabila seorang dai memiliki sifat dapat dipercaya dan jujur maka mad' $\bar{u}$ akan cepat percaya dan menerima ajakan dakwahnya.

\section{5). Pandai Bersyukur}

Orang-orang yang bersyukur adalah orang-orang yang merasakan karunia Allah dalam dirinya, sehingga perbuatan dan ungkapannya merupakan realisasi dari rasa kesyukuran tersebut. Syukur dengan perbuatan berarti melakukan kebaikan, syukur dengan lisan berarti selalu mengucapkan ungkapanungkapan yang baik (kalimāt thayyibāt). Syukur juga mempunyai dua dimensi, syukur kepada Allah dan syukur kepada manusia. Seorang dai yang baik adalah dai yang mampu menghargai nikmat-nikmat Allah dan menghargai kebaikan orang lain.

6). Tulus Ikhlas dan Tidak Mementingkan Pribadi

Apa yang dilakukan seorang dai merupakan bagian dari perhatiannya kepada umat, ia menginginkan umat beriman dan selamat dunia akhirat.

7). Ramah dan Penuh Pengertian

Yaitu menunjukkan sikap hormat dan menghargai kepada siapapun.

\section{8). Tawaduk (Rendah Hati)}

Rendah hati bukanlah rendah diri (merasa terhina dibanding derajat dan martabat orang lain), tawaduk (rendah hati) dalam hal ini adalah sopan dalam pergaulan, tidak sombong, tidak suka menghina, dan mencela orang lain. Dai yang mempunyai sifat tawaduk akan selalu disenangi dan dihormati orang karena tidak sombong dan berbangga diri yang dapat menyakiti perasaan orang lain.

\section{9). Sederhana dan Jujur}

Kesederhanaan adalah merupakan pangkal keberhasilan dakwah, dalam kehidupan sehari-hari selalu ekonomis dalam memenuhi kebutuhan. Sederhana di sini adalah tidak bermegah-megahan, angkuh dan sebagainya, sehingga dengan sifat sederhana seseorang tidak merasa segan dan takut kepadanya.

10). Tidak memiliki Sifat Egois

Ego adalah suatu watak yang menonjolkan keakuan, angkuh dalam pergaulan, merasa diri paling hebat, terhormat, dan lain-lain. Sifat ini benarbenar harus dijauhi oleh dai. Orang yang mempunyai sifat ego hanya akan mementingkan dirinya sendiri, maka bagaimana mungkin seorang dai akan dapat bergaul dan memengaruhi orang lain jika ia sendiri tidak peduli dengan orang lain. 
11). Sabar dan Tawakal

Yaitu sikap pasrah dan menyerahkan segala sesuatu kepada Allah setelah berusaha secara maksimal.

12). Memiliki Jiwa Toleran

Toleransi dapat dipahami sebagai suatu sikap pengertian dan dapat mengadaptasi diri secara positif (menguntungkan bagi diri sendiri maupun orang lain) bukan toleransi dalam arti mengikuti jejak lingkungan. Salah satu contoh ayat yang menunjukkan sifat toleransi dalam Alquran ialah pada surat al-Kāfirūn ayat 6:

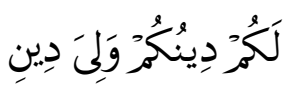

Bagimu agamamu dan bagiku agamaku.

\section{3). Sifat Terbuka (Demokratis)}

Seorang dai adalah manusia biasa yang juga tidak luput dari salah dan lupa. Karena itu agar dakwah dapat berhasil, dai diharuskan memiliki sifat terbuka dalam arti bila ada kritikan dan saran hendaklah diterima dengan gembira, bila ia mendapat kesulitan sanggup bermusyawarah dan tidak berpegang teguh pada pendapat (ide) nya yang kurang baik.

\section{4). Tidak memiliki Penyakit Hati}

Sombong, dengki, ujub, dan iri harus disingkirkan dari sanubari seorang dai. Tanpa membersihkan sanubari dari sifat-sifat tersebut, tidak mungkin tujuan dakwah akan tercapai. Salah satu contoh penyakit hati bila seseorang merasa iri bila temannya mendapat kebahagiaan dunia dan akhirat, sifat tersebut membuat seseorang tidak mungkin mengajak kepada kebaikan bila dirinya sendiri iri melihat sasaran dakwah mendapat kebahagiaan.

\section{5). Istikamah}

Sebuah sikap yang konsisten atau teguh pendirian dalam menegakkan kebenaran. Sifat istikamah dibangun dengan memiliki sikap komitmen atas tugas seorang dai.

\section{6). Rajä' dan Hubb}

Yaitu penuh pengharapan dan optimisme kepada rahmat Allah, yang melahirkan sikap percaya diri dan jauh dari perasaan putus asa. Hubb adalah mencintai Allah di atas segala-galanya. Apa yang dilakukannya atas dasar kecintaan kepada Allah.

17). Sifat Antusias

Sikap semangat dan positif dengan apa yang dilakukannya. Memiliki semangat dan ghirah dalam melaksanakan dakwah Islam. 
b. Sikap Seorang Dai

Sikap dan tingkah laku dai merupakan salah satu faktor penunjang keberhasilan dakwah, masyarakat sebagai suatu komunitas sosial lebih cenderung menilai karakter dan tabiat seseorang dari pola tingkah laku keseharian yang dapat dilihat dan didengar. Memang benar ungkapan para ulama bahwa "Lihatlah apa yang dikatakan dan janganlah melihat siapa (orang) yang mengatakan", namun alangkah baiknya jika tingkah laku dan sikap dai juga merupakan cerminan dari perkataannya (Faizah dan Lalu Muchsin Effendi, 2006: 97). Menurut Faizah dan Lalu Muchsin Effendi di antara sikap-sikap ideal yang harus dimilki oleh para dai adalah:

1). Berakhlak Mulia

Dalam kata lain, memiliki budi pekerti yang mulia dalam seluruh perkataan dan perbuatannya. Rasulullah Saw. sendiri diutus tidak lain untuk memperbaiki moralitas umat manusia, beliau bersabda,

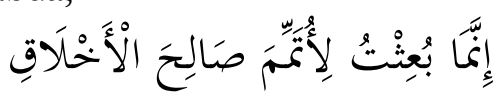

Sesunggubnya aku (Rasulullab) diutus oleb Allab SWT ke dunia ini tak lain hanyalah untuk menyempurnakan akblak. (budi pekerti).

\section{2). Ing Nganso Sung Tuladho, Ing Madya Mangun Karso, Tut Wuri Handayani}

Menjadi teladan atau figur, kreatif inovatif, dan memotivasi secara positif.

3). Disiplin dan Bijaksana

Menepati seluruh norma agama dan masyarakat dan melakukan sesuatu penuh pemikiran dan pertimbangan yang matang.

4). Warak dan Berwibawa

Sikap warak adalah menjauhkan perbuatan-perbuatan yang kurang berguna dan mengindahkan amal saleh, sikap ini dapat menimbulkan kewibawaan seorang dai. Sebab kewibawaan merupakan faktor yang mempengaruhi seseorang untuk percaya menerima suatu ajakan.

5). Berpandangan Luas

Artinya berwawasan luas dan menghindari sikap picik.

6). Berpengetahuan yang Cukup

Dalam arti memiliki pengetahuan yang memadai mengenai segala hal yang berhubungan dengan dakwahnya. Untuk menjadikan pesan dakwah sampai secara tepat kepada mad' $\bar{u}$, seorang dai juga harus memiliki pengetahuan yang memadai tentang semua hal yang berhubungan dengan mad'ü baik bahasa, tradisi, psikologis, budaya, dan temperamen (emosional) mad' $\bar{u}$.

a. Kepribadian yang bersifat jasmani

b. Sehat jasmani 
Segala aktifitas yang dilakukan manusia sudah barang tentu akan optimal bila dikerjakan dalam keadaan sehat, termasuk aktifitas dakwah.

\subsection{Kepribadian yang Bersifat Jasmani}

a. Sehat Jasmani

Seorang dai yang professional berdakwah dengan Jumlah sasaran yang banyak maka sehat jasmani mutlak diperlukan. Kondisi badan yang tidak memungkinkan sedikit banyak dapat mengurangi kegairahan dai dalam melakukan aktivitas dakwah.

\section{b. Berpakaian Sopan dan Rapi}

Menurut Mansur (2000: 47) bagi seorang dai masalah pakaian yang digunakan harus mendapat perhatian serius, sebab pakaian yang digunakan menunjukkan kepribadiannya. Yaitu pakaian yang sesuai dengan tempat, suasana dan keadaan tubuh.

Dalam psikologi dakwah, Achmad Mubarok (1999: 101) menambahkan bahwa seorang dai juga harus memiliki beberapa kemampuan di antaranya:

1). Kemampuan Berkomunikasi

Dakwah adalah mengomunikasikan pesan kepada mad'ü. Komunikasi dapat dilakukan dengan lisan, tulisan, atau perbuatan, dengan kata-kata atau dengan bahasa perbuatan. Komunikasi dapat berhasil manakala pesan dakwah itu dipahami oleh mad' $\bar{u}$ dan pesan dakwah tersebut mudah dipahami bila disampaikan sesuai dengan cara berpikir dan merasa mad' $\bar{u}$.

\section{2). Pemberani}

Dalam tingkatan tertentu seorang dai adalah pemimpin masyarakat. Kapasitas kepemimpinan seorang dai boleh sekurang-kurangnya hanya dalam bidang keagamaan tapi tidak menutup kemungkinan untuk menjalankan fungsifungsi kepemimpinan dalam bidang sosial, ilmu pengetahuan, kebudayaan, ekonomi, bahkan mungkin militer. Daya tarik kepemimpinan seseorang antara lain terletak pada keberaniannya. Keberanian diperlukan dai untuk menyuarakan kebenaran manakala ia dihadapkan pada berbagai tantangan.

\section{Mad'ü (Objek Dakwah) dan Kondisinya}

Pendekatan sistem (system approach) adalah pendekatan yang digunakan dalam aktivitas dakwah. Artinya aktvitas dakwah tidak akan sukses tanpa adanya suatu unsur atau faktor tertentu.

Salah satu unsur dakwah atau mad'ū yakni manusia yang merupakan individu atau bagian dari komunitas tertentu. Mempelajari tentang unsur ini merupakan suatu keniscayaan dalam keberhasilan suatu dakwah (Faizah dan Lalu Muchsin Effendi, 2006: 70).

Manusia sebagai objek psikologi dakwah memiliki sikap dan tingkah laku yang berada satu dengan yang lain. Masing-masing inividu memiliki karakteristik tersendiri yang dipengaruhi oleh hereditas (pewarisan) dan lingkungannya. 
Karakteristik manusia yang dipengaruhi oleh hereditas dan lingkungan merupakan karakteristik manusia apa adanya.

a. Manusia Sebagai Individu

Dalam membentuk kepribadian manusia, faktor intern (bawaan) dan faktor ekstern (lingkaran) saling mempengaruhi sebagai objek dakwah manusia dibedakan oleh berbagai aspek:

1) Sifat-sifat kepribadian seperti, penakut, pemarah, suka bergaul, peramah, sombong dan sebagainya.

2) Intelegensi: aspek kecerdasan seseorang mencakup kewaspadaan, kemampuan belajar, kecepatan berfikir dan kemampuan mengambil kesimpulan.

3) Pengetahuan (knowledge).

4) Ketrampilan (skill).

5) Nilai-nilai (values).

6) Peranan (roles).

b. Manusia Sebagai Anggota Masyarakat (Kelompok)

Manusia secara hakiki merupakan makhluk sosial, sejak lahir ia memerlukan orang lain untuk memenuhi segala kebutuhannya. Masyarakat sebagai objek dakwah atau sasaran dakwah adalah salah satu unsur yang penting dalam sistem dakwah yang lain.

Masyarakat merupakan sasaran dakwah (objek dakwah) tersebut meliputi masyarakat dari berbagai segi: segi sosiologis berupa masyarakat terasing, desa atau kota marginal atau kota besar: segi structural berupa masyarakat pemerintah dan keluarga. Segi sosio structural berupa golongan priyai dan santri. Segi tingkat usia, golongan anak-anak, remaja dan orang tua. Segi okupasional (profesi atau pekerjaan) petani, pedagang dan pegawai dan sebagainya. Segi sosial-ekonomis berupa orang kaya dan orang miskin, segi jenis kelamin, pria dan wanita segi masyarakat khusus berupa; tuna susila, tuna wisma, tuna karya, narapidana dan sebagainya.

Masyarakat dalam perkembangannya di pengaruhi oleh berbagai hal diantaranya:

a. Pengaruh Budaya

Secara umum, kebudayaan meliputi segala sesuatu yang dihasilkan dari cipta rasa dan karsa manusia yang bersifat materi (pakaian, Rumah, mobil dan sebagainya) maupun yang bersifat non materil seperti norma-norma, nilai-nilai, kepercayaan dan lain-lain.

Kebudayaan suatu masyarakat dapat dipengaruhi oleh beberapa faktor antara lain:

1) Faktor Geografis: tempat tinggal suatu masyarakat seperti pendesaan, pegunungan, perkotaan dan sebagainya.

2) Faktor Keturunan: masyarakat keturunan adam dan hawa berkembang menjadi miliaran manusia dengan ciri khas yang berbeda. 
3) Pengaruh dari dunia luar: perpindahan bangsa ke bangsa lain mengakibatkan budaya asli luntur dan bercampur.

b. Organisasi Sosial

Organisasi sosial memiliki pengaruh yang besar dalam kehidupan manusia sebagai contoh sebuah organisasi keagamaan yang merupakan sumber nilai, kebiasaan dan kepercayaan dalam lingkup yang lebih besar Negara dapat dikatakan sebagai organisasi sosial dimana ia merupakan sumber dari normanorma dan nilai bagaimana warganya bersikap dan berperilaku.

\section{Pusat Perhatian Psikologi Dakwah}

Dari uraian di atas maka dapat disimpulkan bahwa pusat perhatian psikologi terhadap proses dan objek dakwah sekurang-kurangnya meliputi empat hal:

1) Analisa terhadap seluruh komponen yang terlibat dalam proses dakwah kepada dai, psikologi dakwah melacak sifat-sifatnya dan mempertanyakan; mengapa dai A berhasil mempengaruhi orang-orang yang didakwahi sedang dai B kok tidak. Tentang (mad'ü dan juga dai) sebagai manusia, sifat-sifatnya dan faktor-faktor apa (internal dan eksternal) yang mempengaruhi perilaku komunikasinya.

2) Bagaimana pesan dakwah menjadi stimulus yang menimbulkan respon mad'u.

3) Bagaimana proses penerimaan pesan dakwah oleh mad'ü, faktor-faktor apa (personal dan situasional) yang mempengaruhinya.

4) Bagaimana dakwah dapat dilakukan secara persuasif, yaitu proses mempengaruhi dan mengendalikan perilaku mad' $\bar{u}$ dengan pendekatan psikologis atau dengan menggunakan cara berpikir dan cara merasa mad'ú.

\section{E. Hakikat dan Fungsi Psikologi Dakwah}

a. Hakikat Psikologi Dakwah

Pada hakikatnya psikologi dakwah sebagai ilmu pengetahuan bertugas mempelajari/membahas tentang gejala-gejala hidup kejiwaan, baik dari dai maupun mad'í yang terlibat dalam proses kegiatan dakwah.

Tugas psikologi dakwah adalah memberikan landasan dan pedoman kepada metodologi dakwah, karena metodologi baru dapat efektif dalam penerapan kerja bila mana didasarkan atas kebutuhan hidup manusia sebagaimana ditunjukkan kemungkinan pemuasnya efek psikologi.

Dengan memperhatikan faktor-faktor perkembangan psikologis beserta ciri-cirinya, maka pesan dakwah yang disampaikan oleh juru dakwah akan dapat meresap dan diterima dalam pribadi sasarannya dan kemudian diamalkannya kepada perasaan yang tulus tanpa adanya ganjalan karena hal tersebut dapat menyentuh dan memuaskan kehidupan rohaninya. Disinilah letak titik berat strategi-strategi dakwah yang sebenarnya yaitu menerima pesan dakwah dengan ikhlas sekaligus mempraktekkannya (Al-Mubarok, 1998: 50). 


\section{b. Fungsi Psikologi Dakwah}

Ukuran keberhasilan suatu penyampaian adalah apabila pesan dakwah yang disampaikan oleh dai sampai kepada mad'ü dalam keadaan utuh, sedangkan ukuran keberhasilan dakwah dalam arti ajakan adalah manakala mad' $\bar{u}$ memenuhi ajakan dai. Pengalaman mengajar bahwa tidak semua ajakan baik diterima sebagai ajakan baik.

Tidak jarang seorang dai yang telah bekerja keras menyampaikan dan mengajak masyarakat kearah kebaikan demi kebahagian mereka justru salah dipahami, konsep kebaikan pada fikiran dan hati dai tidak terkomunikasikan sehingga mad'u tidak dapat menangkapnya atau bahkan ditangkap dengan pemahaman sebaliknya.

Dakwah yang semacam ini dapat disebut sebagai dakwah yang tidak komunikatif dan dakwah yang tidak komunikatif pasti tidak efektif, contohnya senyum ramah ibu tiri belum tentu dipahami oleh anak tirinya. Jadi, suatu pesan baru yang dianggap komunikatif manakala dipahami oleh penerima pesan itu dan untuk menjadikan pesan itu dipahami, komunikator harus memahami kondisi psikologi orang yang menjadi komunikan.

Begitupula para dai manakala ingin agar pesan dakwahnya dipahami maka dakwahnya itu harus disampaikan dengan pendekatan psikologis yakni sesuai dengan tindakan dan kebutuhan jiwa mad'ü sesuai dengan cara berfikir dan cara merasa mad' $\bar{u}$, dakwa seperti itulah yang disebut dakwah persuasif.

Ungkapan Nabi yang sudah popular dalam hal ini adalah "Berbicaralah kepada orang sesuai dengan kadar akal mereka", kadar akal dapat dipahami sebagai tingkatan intelektual biasa juga dipahami sebagai cara berfikir, cara merasa dan kecendrungan kejiwaan lainnya. Akan tetapi melalui komunikasi dakwah yang terus menerus betapapun hasilnya dai dan mad'ú sekurangkurangnya dapat memetik tiga hal yaitu:

1) Menemukan dirinya atau mengerti siapa dirinya dan menempatkan dirinya pada posisi yang tepat.

2) Mengembangkan konsep diri, konsep diri adalah pandangan dan perasaan seseorang tentang diri sendiri.

3) Menetapkan hubungan dengan dunia sekitar.

\section{F. Pendekatan Psikologi Dakwah}

Sebagaimana disebutkan di atas, bahwa sebagai kegiatan dakwah adalah peristiwa komunikasi. Komunikasi menarik perhatian banyak disiplin ilmu, dengan pendekatan yang berbeda-beda. Sosiologi misalnya, mempelajari komunikasi dalam konteks interaksi sosial untuk mencapai tujuan-tujuan kelompok. Dalam pandangan sosiolog, komunikasi adalah proses megubah kelompok manusia menjadi kelompok manusia yang berfungsi.

Menurut teori komunikasi, (Fisher, 1978: 136-142), proses dakwah dapat dilihat sebagai kegiatan psikologis yang mencakup hal-hal sebagai berikut:

Pertama, diterimanya stimuli (rangsang) oleh organ-organ penginderaan, berupa orang, pesan, warna atau aroma. 
Kedua, rangsang yang diterima mad' $\bar{u}$ berupa-rupa, warna, suara, aroma dan pesan dakwah yang disampaikan dai-dai itu kemudian diolah di dalam benak mad'ū (hadirin), dihubung-hubungkan dengan pengalaman masa lalu masingmasing dan disimpulkan juga oleh masing-masing. Meskipun pesan dakwah oleh dai itu dimaksudkan A, tapi kesimpulan mad'ü boleh jadi B, C, atau D.

Ketiga, untuk merespon terhadap ceramah atau seruan ajakan dai (misalnya tepuk tangan, berteriak, mengantuk atau karena bosan kemudian meninggalkan ruangan), pikiran hadirin bekerja, mengingat-ingat apa yang pernah terjadi di masa lalu. Dari memori itu para hadirin kemudian meramalkan bahwa jika hadirin melakukan tindakan X, maka dai akan melakukan tindakan Y, jika X maka Y.

Keempat, setelah itu barulah hadirin akan merespon terhadap ajakan dai, dan respon dari hadirin itu merupakan umpan balik bagi dai.

\section{G. Interaksi Psikologi Dai dan Mad'ū}

Adapun dalam proses psikologi dakwah, dalam arti interaksi sosial antara dai dan mad'u $\bar{u}$ sekurang-kurangnya terkandung tiga makna:

1) Bahwa, baik dai maupun mad'u sebenarnya terlibat dalam proses belajar, baik dari segi berpikir maupun dari sudut merasa. Mad' $\bar{u}$ belajar kepada dai, tapi dai juga belajar kepada umpan balik yang disampaikan oleh mad' $\bar{u}$.

2) Antara dai dan mad'ú terjadi proses penyampaian dan penerimaan lambang-lambang dalam berkomunikasi (tepuk tangan lambang suka, gaduh dan ngantuk lambang penolakan).

3) Adanya mekanisme penyesuaian diri antara dai dan mad'ú. Bentuk penyesuaian diri itu bisa permainan peranan, identifikasi, atau agresi. Jika hadirin ramai-ramai meninggalkan tempat acara atau berbicara sendiri atau mengantuk semua, padahal mubalighnya masih pidato di atas mimbar, maka apa yang dilakukan hadirin menurut pandangan psikologi sebenarnya merupakan penyesuaian diri dari ceramah yang tidak komunikatif.

Proses dakwah dikatakan berhasil dan efektif ketika tujuan dari dakwah itu sendiri telah tercapai. Tercapainya tujuan dakwah ada beberapa tahap, antara lain:

a. Tahap kognitif, adalah ketika seorang mad'ü mampu menangkap, mengerti dan memahami apa yang disampaikan oleh seorang dai.

b. Tahap afeksi, adalah tahap berikutnya setelah tahap kognitif. Pada tahap ini, seorang mad'u diharapkan mampu merasakan dan merenungkan secara lebih mendalam apa yang telah disampaikan oleh dai, tidak hanya sekedar memikirkan saja.

c. Tahap psikomotor, adalah tahap di mana seorang mad' $\bar{u}$ telah mampu mengaplikasikan atau menjalankan apa yang sebelumnya telah disampaikan oleh seorang dai, dan setelah mad'ü melakukan perenungan secara mendalam. Sehingga kesadaran benar-benar muncul dalam diri seorang mad'ú tentang apa sesungguhnya kewajibannya terhadap Tuhannya, apa sesungguhnya tugas dan kewajibannya di dunia ini agar 
pada saat menjalankan tugas dan amanahnya, seorang mad' $\bar{u}$ benar-benar melakukan dengan berdasarkan kesadarannya sendiri.

\section{H. Penutup}

Berdasarkan kajian diatas dapat disimpulkan bahwa peran dan fungsi dai erat sekali hubungannya dengan perspektif psikologi dakwah. Karena ketika seseorang berdakwah (dai) maka ia perlu bahkan harus mengetahui kondisi psikologis obyek yang didakwahi (mad'û) agar apa yang disampaikan nantinya dapat tersampaikan dengan baik. Karena dakwah itu sendiri merupakan suatu kegiatan yang mempengaruhi orang lain agar mau merubah tingkah lakunya dan mengikuti sesuai dengan yang disyariatkan oleh agama (Islam). Tidak hanya itu, dalam hal ini seorang dai juga diharapkan dapat melaksanakan tugas dakwah dengan pendekatan kejiwaan sehingga hal yang diharapkan peran dan fungsi seorang dai benar-benar dapat dipahami oleh seorang dai itu sendiri sebagai mubaligh dan kondisi objek dakwah sebagai mad'ü.

Dalam mempengaruhi orang lain agar orang lain dapat mengikuti apa yang kita inginkan maka kita harus melakukan beberapa pendekatan, dan bisa dibilang pendekatan psikologis adalah pendekatan yang paling penting dan yang paling berpengaruh apakah nantinya orang lain $\left(\operatorname{mad}^{\prime} \hat{u}\right)$ itu dapat menerima apa yang disampaikan oleh dai dan menjalankannya. Dan perlu kita ketahui juga bahwasannya tujuan utama dari dakwah adalah bagaimana nantinya seorang dai dapat memahami peran dan fungsinya sebagai pendakwah secara psikologi dakwah, dan kepada seorang mad'ú dapat atau mau menjalankan apa yang disampaikan oleh seorang dai, bukan hanya sekedar dipahami, direnungkan dan dirasakan saja tapi bagaimana agar seorang mad' $\bar{u}$ benar-benar menjalankan apa yang disampaikan oleh dai dengan penuh kesadaran dari dirinya sendiri. 


\section{DAFTAR KEPUSTAKAAN}

Abda, Slamet Muhaemin. Prinsip-Prinsip Metodologi Dakwah. Surabaya: Al-Ikhlas, 1994.

Al-Mubarok. Al-Qur'an dan Terjemahnya. Semarang: Asy-Syifa, 1998.

Arifin, H.M. Psikologi dan Beberapa Aspek Kehidupan Rohaniah Manusia. Jakarta: Bulan Bintang, 1976.

AS, Enjang dan Aliyudin. Dasar-Dasar Ilmu Dakwah: Pendekatan Filosofis Dan Praktis. Bandung: Widya Padjadjaran, 2009.

Faizah dan Lalu Muchsin Effendi, Psikologi Dakwah. Cet. I. Jakarta: Kencana, 2006.

Fisher. Perspektives on Human Communication. New York: Washington Square Press, 1978.

Hasjmy, Dustur Dakwah dalam Al-Qur'an. Jakarta: Bulan Bintang, 1994.

Hilgard, Ernest R. Introduction to Psychology. USA: Brace and World Inc, 1962.

Mansur, Mustafa. Fiqhud Dakwah. Jakarta: Al-I'tishom, 2000.

Mubarok, Achmad. Psikologi Dakwah. Jakarta: Pustaka Firdaus, 2006.

Ruch, Jhon C. Psychology, The Personal Science. California: Wod Wodworth Publishing Company, 1984.

Sarwono, Sarlito Wirawan. Pengantar Umum Psikologi Jakarta: Bulan Bintang, 2000.

Tasmara, Toto. Komunikasi Dakwah. Jakarta: CV Gaya Media Pratama, 1997. 